\title{
FAKTOR-FAKTOR YANG MEMPENGARUHI BEHAVIOURAL INTENTION
}

\author{
Lily Purwianti \\ Karen Tio
}

Universitas Internasional Batam

Email: lpurwianti@yahoo.com

Submitted: Apr 20, 2017; Reviewed: Apr 23, 2017; Accepted: May 21, 2017

\begin{abstract}
Internet is one of the electronic media with faster development than other electronic media. Survey proves that people use internet for entertainment, socialize, seeking information and purchasing goods or service through online. Survey's result also show online shopping trend keeps on increasing due to increase on consumer's need for e-commerce and other benefits that could be gained if consumer were buying things through online compared to buying directly. The purpose of this study was to evaluate the effect of e-service's elements such as e-service quality, customer satisfaction, attitude towards the website and behavioural intention to know how important is the factors of eservice in online shop's marketing strategy. The respondents in this study are customers that ever purchase from four Indonesia online shop website. The sample's criteria used in this study is non probability with purposive sampling method. The data analysis method are simple regression and multiple regression, Samples were collected by distributing 440 questionnaires in which the rate of return is 387. The results of this study indicate that e-service quality have a significant effect to customer satisfaction, e-service quality have significant effect to attitude towards the website, customer satisfaction have a significant effect to attitude towards the website, customer satisfaction have a significant effect to behavioural intention, brand image have a significant effect to customer satisfaction, brand image have a significant effect to behavioural intention and attitude towards the website have a significant effect to behavioural intention.
\end{abstract}

Keywords: e-service quality, customer satisfaction, attitude towards the website, brand image dan behavioural intention.

\section{PENDAHULUAN}

Kemajuan akan penggunaan internet ini telah merambah di berbagai bidang dan sektor kehidupan, baik lingkungan sosial, sekolah, rumah tangga dan dunia kerja, namun juga masuk ke area hiburan. Penggunaan internet ini terus meningkat tajam di banyak negeri termasuk Indonesia. Seiring dengan hal tersebut produk dan jasa dari para peritel e-commerce telah berubah secara signifikan dalam beberapa tahun terakhir dimana tingkat popularitas belanja dengan cara online atatu online shopping telah meningkat dengan pesat (https://www.tabloidpulsa.co.id/news/lifestyle).

Tentu saja berkembang dan meluasnya pemakaian internet ini menjadi saran ampuh bagi para produsen, pemasar, dan stakeholder lain yang berkepentingan terhadap industri jasa maupun layanannya yang dihubungkan dengan para klien, rekanan maupun pesaing bisnisnya. Internet dapat memberi ruang penciptaan pasar baru sekaligus dapat menjadi ruang mendatangkan pesaing baru jika pihak lawan dapat memberikan layanan melalui penggunaan internet ini dengan lebih baik dari perusahaan yang lain. Populasi pengguna internet di Indonesia telah mencapai 83.7 juta orang pada tahun 2014 dan diprediksi pada tahun 2017 jumlah tersebut akan mencapai angka 112 juta orang dan akan mengalahkan Jepang yang pertumbuhan pengguna internetnya melambat. Secara keseluruhan diproyeksikan pengguna internet akan mencapai 3.6 milyar orang pada tahun 2018 (https://komifo.go.id).

Online shop atau berbelanja barang atau pemesanan jasa melalui internet telah menjadi 
hal yang umum untuk dilihat. Banyak sekali situs-situs komersial yang menawarkan cara berbelanja dengan metode penggunaan internet. Dalam proses pembelanjaan ini, konsumen benar-benar diberikan suatu ruang yang nyaman, karena para konsumen tidak perlu beranjak dari tempatnya dalam melakukan proses pembelian atau transaksi. Konsumen cukup di tempat dan melalui perangkat elektroniknya semua kebutuhan untuk melakukan transaksi dapat diselesaikan. Terdapat beberapa keuntungan dalam berbelanja online yaitu, Para konsumen belanja online dapat memperoleh barang atau jasa yang diinginkannya tanpa harus pergi ke tempat perbelanjaan, tetapi cukup memilih apa yang diinginkanya dengan membuka website yang disediakan oleh penyedia jual beli online dan membayarnya dengan cara mentransfer uang ke penjual. Dengan demikian para pembeli dapat menghemat waktu dan lebih mudah untuk mendapatkan barang atau jasa yang diinginkan karena tidak perlu berdesak-desakan dan mengangkut barang yang dibeli. Selain itu para pembeli juga mempunyai pilihan yang lebih luas dan lebih leluasa untuk membandingkan harga berdasarkan informasi yang disajikan dalam situs-situs yang menawarkan barang tersebut (http://lifestyle.liputan6.com/read/2144183/5manfaat-belanja-online).

Berdasarkan riset yang dilakukan oleh MarkPlus Insight, pertumbuhan pengunaan internet di indonesia terus meningkat pada tahun 2014, Indonesia memiliki 78 juta pengguna internet dan diperkirakan 100 juta orang indonesia akan terhubung ke internet pada tahun 2016. Menurut MarkPlus Insight, rata-rata pengguna internet adalah pria, tetapi lebih dari $55 \%$ pembeli online adalah perempuan dan hasil riset juga menunjukkan sekitar $50 \%$ hingga 80 $\%$ dari pengguna internet didominasi oleh anak muda berusia 15-30 tahun.

Ada beragam dan ribuan situs yang menjalankan model pelayanan pelanggan dengan cara seperti ini, contohnya; Olx.co.id, Tokopedia.com, Berniaga.com, dan Kaskus.co.id serta masih banyak lagi. Jenis dan kategori barang yang diperdagangkan pun beragam dari fashion, sampai ke peralatan rumah tangga, dan beragam macam tiket serta kebutuhan yang lain. Di Indonesia sudah ada lebih dari 350 toko virtual dan kombinasi toko virtual dan fisik yang meramaikan bisnis online shopping seperti dikutip dari situs Asosiasi Penyelenggara Jasa Internet Indonesia (www.apjii.or.id)
Toko online telah terbukti mampu mengeksploitasikan peluang pasar dan pertumbuhannya yang pesat membuat jumlah perusahaan yang terjun ke bisnis online terus bertambah dikarenakan banyaknya jumlah perusahaan yang selalu mencari peluang pasar yang baru untuk mengembangkan bisnis mereka. Oleh karena itu $e$-service memiliki peran penting untuk menarik pelanggan untuk mengunjungi website tersebut.

Untuk dapat bersaing dan meningkatkan perkembangan online shop, pengelola online shop harus mampu memperhatikan berbagai faktor-faktor yang dapat memicu behavioural intention seperti memberikan layanan yang bagus (e-service quality). E-service quality dapat meningkatkan behavioural intentions seperti revisiting the site, consumer duration of visit to the site, purchase intention dan word-of mouth yang positif dimana hal ini dapat memaksimalkan keuntungan kompetitif kegiatan perdagangan di internet (e-commerce). Meningkatkan kepuasaan konsumen (customer satisfaction) Hasil penelitian Collier dan Bienstock (2006), tentang e-retail industries menemukan bahwa pelanggan website yang puas cenderung akan berkunjung kembali, melakukan pembelian, dan merekomendasikan website tersebut. Pembelian produk pada masa kini banyak dipengaruhi oleh Brand awareness dan Brand image yang yang secara langsung akan mempengaruhi Repurchase Intention (FranzRudolf Esch et al, 2006). Ketika konsumen merasa puas maka akan menunjukkan sikap yang positif terhadap situs yang konsumen kunjungi (attitude toward the website) Menurut Ajzen dan Fishbein dalam Dharmesta (2007) perilaku (behavior) individu dapat diperkirakan berdasarkan niat (intention) mereka, dimana lebih tepatnya ia diperkirakan dari sikap (attitudes) mereka terhadap perilaku dan norma subjektif (subjective norms), sehingga memutuskan untuk berkunjung kembali (behavioural intention) (Carlson dan O'Cass, 2010).

Adapun permasalahan yang akan dibahas di dalam penelitian ini adalah sebagai berikut:

1. Apakah e-service quality berpengaruh signifikan terhadap customer satisfaction?

2. Apakah e-service quality berpengaruh signifikan terhadap attitude towards the website? 
3. Apakah brand image berpengaruh signifikan terhadap customer satisfaction?

4. Apakah consumer satisfaction berpengaruh signifikan terhadap attitude towards the website?

5. Apakah brand image berpengaruh signifikan terhadap behavioural intention?

6. Apakah customer satisfaction berpengaruh signifikan terhadap behavioural intention?

7. Apakah attitude towards the website berpengaruh signifikan terhadap behavioural intention?

Adapun tujuan dari penelitian ini adalah sebagai berikut:

1 Untuk mengetahui pengaruh signifikan antara e-service quality terhadap customer satiscfaction.

2 Untuk mengetahui pengaruh signifikan e-service quality terhadap attitude towards the website.

3 Untuk mengetahui pengaruh signifikan brand image terhadap customer satisfaction.

4 Untuk mengetahui pengaruh signifikan customer satisfaction terhadap attitude towards the website.

5 Untuk mengetahui pengaruh signifikan brand image terhadap behavioural intention.

6 Untuk mengetahui pengaruh signifikan customer satisfaction terhadap behavioural intention.

7 Untuk mengetahui pengaruh signifikan attitude towards the website terhadap behavioural intention.

\section{KERANGKA TEORITIS PERUMUSAN HIPOTESIS}

\section{Behavioural intention}

Menurut Namkung dan Jang (2007) behavioural intention adalah tingkah laku dari konsumen yang setia atau loyal terhadap perusahaan tersebut sehingga bersedia merekomendasikan kepada orang lain karena telah mendapatkan layanan yang baik dari perusahaan. Kotler (2014) behavioural intention adalah kondisi dimana pelanggan memiliki intensi atau sikap loyal pada brand, product dan company dan secara rela menceritakan keunggulannya kepada pihak lain. Sementara menurut Schiffman et al. (2008) menjelaskan bahwa behavioural intention menentukan kemungkinan konsumen akan melakukan tindakan tertentu di masa yang akan datang.

Dharmmesta (2008) mendefinisikan bahwa behavioral intention merupakam suatu perilaku atau sikap konsumen yang memiliki keinginan untuk menggunakan jasa secara terus menerus. Saha dan Theingi (2009) mendefinisikan behavioural intention sebagai kemungkinan pelanggan untuk melakukan suatu perilaku tertentu misalnya word-of-mouth yang positif tentang suatu penyedia jasa kepada orang lain, memiliki niat membeli ulang dan kesetiaan terhadap penyedia penyedia jasa.

Dari beberapa pendapat tentang behavioural intention maka dapat disimpulkan bahwa variabel behavioural intention merupakan tujuan akhir. Apabila suatu produk mempunya behavioural intention yang menguntungkan maka perusahaan tersebut akan dapat bertahan dan memenangkan persaingan. Salah satu dari behavioural intention yang menguntungkan adalah adanya sikap posistif tentang suatu produk atau penyedia jasa. Sikap positif ini dapat berupa word of mouth yang posistif. word of mouth ini meruapakan promosi yang berbiaya murah dan memepunyai efek yang luar biasa terhadap kelangsungan hidup perusahaan. Apabila konsumen kita menyebarkan berita bagus kepada orang alain atau teman -teman nya makan akan mendorong terjadinya pembelian.

Behavioural intention yang posistif juga mempunyai manfaat yang banyak perusahaan. Salah satunya adalah konsumen menjadi loyal terhadap produk atau jasa yang digunakan. Loyalitas merupakan hal yang menjadi tujuan dari perusahaan akan produk atau jasa. Banyak sekali perusahaan menggunakan segala cara agar konsumen menjadi loyal terhadap brand atau produk mereka.

\section{E-service Quality}

E-service quality sebagai penilaian konsumen terhadap kualitas pelayanan secara keseluruhan dari suatu bisnis internet. Menurut Zeithaml dalam Kotler (2010) e-service quality dalam lingkungan layanan tradisional merupakan penilaian konsumen secara global terhadap keunggulan suatu pelayanan jika dibandingkan dengan kualitas layanan yang ditawarkan pesaingnya. Rowley (2006) mengartikan $e$ - 
service sebagai perbuatan, usaha atau kinerja yang disampaikan melalui penggunaan teknologi informasi sebagai perantara.

E-service quality sebagai kemampuan suatu situs untuk menyediakan bantuan untuk berbelanja secara efisien dan efektif, ketika melakukan pembelian dan ketika menyampaikan produk dan jasa. E-service quality sebagai penilaian dan pertimbangan konsumen secara keseluruhan terhadap kesempurnaan dan kualitas dari pelayanan e-service dalam virtual market place. e-service quality sebagai suatu batasan dimana suatu website menyediakan fasilitas belanja, pembelian, produk dan pelayanan jasa secara efisien dan efektif.

E-service quality sangat berdampak sekali terhadap kepuasan konsumen dan loyalitas konsumen. Konsumen dalam melakukan pembelian pasti dia akan melihat bagai mana service quality yang diberikan oleh perusahaan. Service quality juga diperlukan pada sistem pembelian on-line. Konsumen akan melihat apakah website menyediakan fasilitas belanja, pembelian, produk dan pelayanan jasa secara efisien dan efektif. Dengan kemajuan teknologi saat ini dan dengan keterbatasan waktu yang dipunyai konsumen makan pembelian online merupakan pilihan pertama bagi konsumen. Maka dengan itu E-service quality sangat diperlukan dan harus diperhatikan.

\section{Attitude Toward the Website}

Beberapa peneliti mengartikan attitudes toward the web site konsumen sebagai tanggapan baik maupun tidak baik yang ditujukan terhadap suatu web site. Dharmmesta (2004) memberi pengertian attitude sebagai dorongan psikologi yang ditunjukkan dengan menilai seberapa tinggi rasa suka atau ketidaksukaan seseorang terhadap sesuatu. Kotler (2014) mendefinisikan consumer attitude sebagai penilaian seseorang secara keseluruhan terhadap suatu konsep, dimana diasumsikan semakin positif penilaian seseorang terhadap suatu produk/merek maka semakin tinggi kemungkinan seseorang akan membeli atau menggunakannya.

Attitude toward website yang positif terbukti memiliki kaitan dengan tiga atribut dari e-service quality yaitu entertainment informativeness dan organization. Berbagai faktor e-service quality terbukti berpengaruh signifikan positif terhadap attitudes toward the web site konsumen (Vijayasarathy, 2004).

Sikap atau Attitude merupakan tanggapan yang timbul sebagai akibat, melihat, merasakan 18 dan mengetahui tentang sesuatu . Sikap ini dapat mengarah pada arah yang baik ataupun sebaliknya terhadap suatu objek yang cenderung muncul secara konsisten dan sikap cenderung konsisten daripada perilaku atau behavior. Mosavi dan Ghaedi (2011) mengemukakan bahwa terdapat pengaruh yang positif attitude terhadap behavioural intention, Attitude ini dapat dibentuk dari pengalaman, pembelajaran dan proses di masa lalu dan sekarang yang membentuk nilai dan norma terhadap sesuatu. Proses ini dibentuk melalui pemikiran kognitif, afektif dan konatif yang pada akhirnya dapat membentuk pola atau kebiasaan pada diri seorang pelanggan. Sikap yang baik pelanggan pada sebuah website banyak dipengaruhi oleh easy to use, praktis, dan memberi nilai prestise pada pelanggan. Hasil penelitian terdapat pengaruh attitude terhadap behavioral intention.

Attitudes toward the web site konsumen sebagai tanggapan baik maupun tidak baik yang ditujukan terhadap suatu web site. consumer attitude sebagai penilaian seseorang secara keseluruhan terhadap suatu konsep, dimana diasumsikan semakin positif penilaian seseorang terhadap suatu produk/merek maka semakin tinggi kemungkinan seseorang akan membeli atau menggunakannya.

\section{Brand Image}

Menurut Kotler dan Armstrong, (2014) brand image yang baik secara langsung akan memberikan kepuasan pelanggan meningkat sehingga pelanggan yang melakukan pembelian ulang dari perusahaan yang sama, memberitahukan ke konsumen yang lain yang potensial dari mulut ke mulut dan menjadi penangkal serangan dari pesaingnya. Sehingga dapatlah dikatakan bahwa keberhasilan suatu perusahaan sangatlah ditentukan oleh retensi pelanggannya

Beberapa penelitian yang berhubungan customer satisfaction sebagai titik awal tumbuhnya loyalitas pelanggan .Kepuasan pelanggan telah diakui sebagai determinan penting loyalitas pelanggan. Kepuasan pelanggan dapat dikonseptualisasikan sebagai keseluruhan evaluasi pelanggan atas performance dari suatu penawaran . Hasil evaluasi terhadap suatu brand image dipilih memenuhi atau melampaui ekspektasinya, maka pelanggan tersebut akan menunjukkan sikap positif, dan memiliki keinginan untuk membeli/menggunakan kembali. keinginannya untuk bertindak sebagai referensi bagi orang lain (advocacy intentions). Intinya 
bahwa kepuasan pelanggan akan memainkan peran penting dalam menjelaskan alasan pelanggan dipandang loyal.

Customer satisfaction sebagai titik awal tumbuhnya loyalitas pelanggan. Kepuasan pelanggan telah diakui sebagai determinan penting loyalitas pelanggan. Kepuasan pelanggan dapat dikonseptualisasikan sebagai keseluruhan evaluasi pelanggan atas performance dari suatu penawaran. Hasil evaluasi terhadap suatu brand image dipilih memenuhi atau melampaui ekspektasinya, maka pelanggan tersebut akan menunjukkan sikap positif, dan memiliki keinginan untuk membeli/menggunakan kembali. keinginannya untuk bertindak sebagai referensi bagi orang lain (advocacy intentions). Intinya bahwa kepuasan pelanggan akan memainkan peran penting dalam menjelaskan alasan pelanggan dipandang loyal.

\section{Customer Satisfaction}

Menurut Kotler (2014), costumer satisfaction merupakan suatu reaksi yang cenderung muncul setelah suatu pelayanan diberikan. Menurut Zeithaml et al. (2006), customer satisfaction merupakan dugaan konsumen terhadap suatu jasa, apakah suatu jasa telah memenuhi kebutuhan dan ekspektasi dari konsumen. Customer satisfaction adalah respon dari konsumen yang merasa kebutuhannya terpenuhi dan merupakan penilaian apakah fitur suatu produk atau jasa ataupun produk itu sendiri mampu memenuhi tingkat kebutuhan konsumsi sesuai dengan yang diinginkan konsumen ataupun melebihi dari apa yang diharapkan.

Customer satisfaction memiliki hubungan positif terhadap attitude towards the website (Carlson dan O'Cass., 2010). Kepuasaan dari konsumen dan perilaku/sikap konsumen menunjukkan peningkatan dalam kepuasaan konsumen terhadap atribut sebuah situs berhubungan dengan pembentukan perilaku positif terhadap situs tersebut. Ketika kepuasaan konsumen diperhitungkan sebagai after-service, maka tingkat kepuasaan konsumen akan terbentuk sebagai hasil dari kepuasan-kepuasan kosumen setiap kali menggunakan jasa.

\section{Hipotesis Penelitian}

Menurut Collier dan Bienstock (2006) dan Cristobal et al. (2007) berbagai macam atribut kualitas terbukti memiliki pengaruh signifikan positif terhadap customer satisfaction. Chang et al. (2009) mengindikasikan bahwa e-service quality memiliki pengaruh positif terhadap customer satisfaction yang pada akhirnya dapat mengarahan atau menciptakan kesetiaan konsumen (customer loyalty). Penelitian Yang dan Fang (2007) mengindikasikan kemudahan penggunaan (ease of use) untuk navigasi merupakan hal penting yang mempengaruhi customer satisfaction. Para ahli telah membuktikan bahwa adanya hubungan positif antara e-service quality dan e-satisfaction $E$ service quality yang telah ditingkatkan dapat membuat retailers terlihat lebih menarik sehingga membantu mereka untuk mendapatkan tingkat customer satisfaction dan retention yang lebih tinggi. Para ahli telah memastikan adanya pengaruh e-quality terhadap satisfaction (Lee dan Lin, 2008; Collier dan Bienstock, 2006; Fassnacht dan Kose, 2007; Cristobal et al., 2007; Shamdasani et al., 2008, Saif, 2009, Gounaris, Dimitriadis dan Stathakopoulos , 2010). Carlson dan O'Cass (2010) menyebutkan e-service quality memberikan pengaruh signifikan positif terhadap consumer satisfaction, e-service quality memberikan pengaruh signifikan positif terhadap attitude toward the website, Dari beberapa pendapat diatas maka dapat disusun hipotesa penelitian sebagai berikut:

$\mathrm{H} 1$ : e-service quality berpengaruh signifkan positif terhadap customer satisfaction

$\mathrm{H} 3$ : e-service quality berpengaruh signifikan positif terhadap attitude towards the website

Menurut Kanuk (2006) hubungan antara brand image dengan customer satisfaction mengatakan bahwa brand image mempengaruhi perilaku pembeli, dimana pelanggan yang puas cenderung menjadi pelanggan yang loyal, namun pelanggan yang loyal tidak perlu puas. Menurut Kotler dan Armstrong, (2014) brand image yang baik secara langsung akan memberikan kepuasan pelanggan meningkat sehingga pelanggan yang melakukan pembelian ulang dari perusahaan yang sama, memberitahukan ke konsumen yang lain yang potensial dari mulut ke mulut dan menjadi penangkal serangan dari pesaingnya. Sehingga dapatlah dikatakan bahwa keberhasilan suatu perusahaan sangatlah ditentukan oleh retensi pelanggannya. Hubungan antara brand image dan customer satisfaction dan loyalitas nampak menjadi lebih kompleks daripada yang diharapkan . Dalam perspektif relasional, brand image merupakan variabel yang memediasi hubungan antara sikap tertentu dan behavioral outcomes (Dharmmesta, 2006). Kepuasan yang 
didorong oleh kepercayaan pada suatu merek akan lebih menjelaskan loyalitas sesungguhnya.

Penelitian lainya yang berhubungan dengan hubungan brand image terhadap behavioral intention di pengaruhi oleh Brand Knowledge atau Pengetahuan akan merek terdiri dari Brand Awarenes atau kesadaran akan merek dan Brand Image ( Khan dan Majeed, 2012). Pembelian produk pada masa kini banyak dipengaruhi oleh Brand awareness dan Brand image yang yang secara langsung akan mempengaruhi Repurchase Intention (FranzRudolf Esch et al, 2006)

Brand image yang kuat tidak hanya meningkatkan diferensiasi antara pesaing, tetapi juga memperkuat kepercayaan, dan mempunyai hubungan yang positif terhadap perilaku pelanggan, meminimalkan risiko yang dirasakan, dan merupakan kualitas tinggi dari titik pandang pelanggan (Chiu et al.2010), preferensi merek tergantung pada penciptaan tingginya tingkat kesadaran merek (Phau et al. 2000 dalam Chiu et al .2010) dan brand image positif (Dolekoglu et al. 2007, Hosany et al.2006 dan dalam Chiu et al. 2010). Brand Image memiliki hubungan terhadap perilaku konsumen dalam membeli suatu barang, terutama di mana konsumen sulit untuk membedakan produk atau jasa berdasarkan atribut tidak berwujud Cretu et al. (2007).

$\mathrm{H} 2$ : brand image berpengaruh signifikan positif terhadap customer satisfaction

H5 : brand image berpengaruh signifikan positif terhadap behavioural intention

Hasil penelitian Collier dan Bienstock (2006), Cristobal et al. (2007), tentang e-retail industries menemukan bahwa pelanggan website yang puas cenderung akan berkunjung kembali, melakukan pembelian, dan merekomendasikan website tersebut. Konsumen yang tidak puas cenderung mencari informasi tentang website alternatif yang lain, lebih setia terhadap website kompetitor dan menolak untuk membangun hubungan yang lebih dekat dengan website yang tersebut.

Hasil dari penelitian-penelitian membuktikan bahwa service quality mempengaruhi behavioural intention secara tidak langsung melalui satisfaction ( $\mathrm{Hu}$ et al., 2009; Yu et al., 2006). Adanya pengaruh langsung atau tidak langsung antara service quality, perceived value dan satisfaction terhadap behaviour intention (Chang et al., 2009; Hu et al., 2009). Customer satisfaction merupakan perantara penting antara behavioural intention 20 dengan actual behaviour. service quality dan satisfaction merupakan pemicu behavioural intention yang cukup baik.

Customer satisfaction merupakan penyebab utama terjadinya pengulanggan perilaku pembelian (repeat purchase behaviour), customer satisfaction secara keseluruhan dari suatu produk maupun jasa memiliki kaitan yang kuat dengan behavioural intention. Yen dan Lu (2008) mengindikasikan bahwa satisfaction mempengaruhi niat konsumen untuk mengulangi pembelian barang atau penggunaan jasa. Han dan Ryu (2006) menemukan bahwa meningkatkan customer satisfaction merupakan hal penting untuk memicu munculnya niat konsumen untuk berkunjung kembali (revisit intention) dan merekomendasikan retailer ke pelanggan lainnya.

Customer satisfaction memiliki hubungan positif terhadap attitude towards the website (Carlson dan O'Cass., 2010). Kepuasaan dari konsumen dan perilaku/sikap konsumen menunjukkan peningkatan dalam kepuasaan konsumen terhadap atribut sebuah situs berhubungan dengan pembentukan perilaku positif terhadap situs tersebut. Penelitian Bontis, Booker, dan Serenko (2009) terhadap 8.098 orang responden di Canada untuk mengetahui pengaruh nama atau brand organisasi sebagai mediasi terhadap sikap atau attitude konsumen dalam memberikan rekomendasi pelayanan dan loyalitas pelanggan, menyimpulkan bahwa kepuasan pelanggan berpengaruh positif dalam meningkatkan reputasi atau nama baik organisasi. Penelitian ini juga menemukan bahwa reputasi atau nama baik atau brand image dapat memediasi hubungan antara satisfaction, loyalty, dan reputasi atau nama baik atau brand image dapat memediasi hubungan antara kepuasan dan sikap atau attitude konsumen untuk merekomendasikan pengalamanya. Heru (2012) dan Haves (2012) customer satisfaction yang dirancang dalam layanan elektornik yang seiraman dengan kondisi pelanggan dapat meningkatkan persepsi dan sikap yang positif terhadap cara pandang dan niat perilaku. Sikap yang baik memberikan potensi terhadap suatu niat dan tindakan yang sesuai dengan harapan pemberi stimulus yang dirancang oleh perusahaan atau marketer.

H4: customer satisfaction berpengaruh signifikan positif terhadap attitude towards the website 
Jurnal Manajemen Maranatha — Vol. 17 Nomor 1, November (2017)

H6 : customer satisfaction berpengaruh signifikan positif terhadap behavioural intention

$\mathrm{H} 7$ : attitude towards the website berpengaruh signifikan positif terhadap behavioural intention

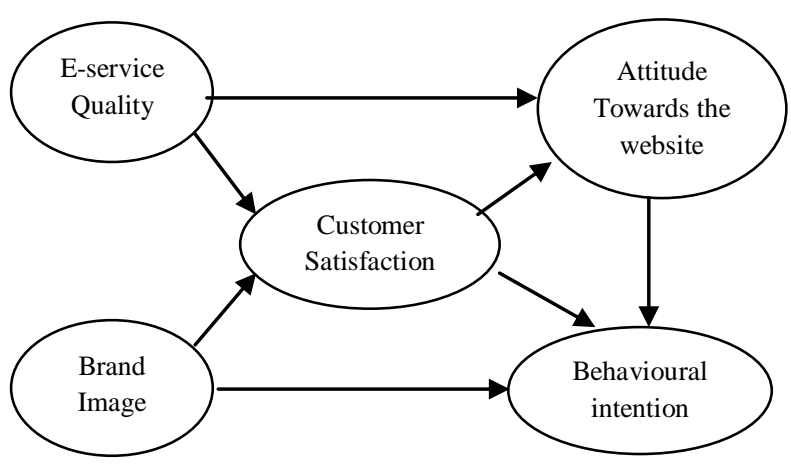

Gambar 1 Model Faktor-Faktor yang mempengaruhi Behavioral Intention

\section{METODE PENELITIAN \\ Objek Penelitian}

Populasi dalam penelitian ini adalah pelanggan toko online di Indonesia, khususnya mahasiwa/I di kota Batam, yang telah menggunakan perangkat teknologi dalam berbelanja atau melakukan transaksi pembelian menggunakan teknologi e-commerce. Penulis memilih mahasiswa sebagai sampel penelitian dikarenakan kecendrungan mahasiswa sebagai profesi masyarakat Indonesia yang paling sering menggunakan internet dibandingkan profesi lainnya dimana berdasarkan hasil riset MarkPlus Insight yang menunjukkan sekitar $50 \%$ hingga $80 \%$ dari pengguna internet di Indonesia didominasi oleh masyarakat yang berusia dari 15 tahun sampai dengan 30 tahun

(http://tekno.kompas.com/read/2011/10/28/1653 4635/Naik. 13.Juta..Pengguna.Internet.Indonesia. 55.Juta.Orang).

\begin{tabular}{|c|c|c|c|}
\hline Variabel & $\begin{array}{l}\text { Definisi } \\
\text { Operasional } \\
\text { variabel }\end{array}$ & $\begin{array}{l}\text { Skala } \\
\text { Pengukuran }\end{array}$ & Sumber \\
\hline $\begin{array}{l}\text { Behavioral } \\
\text { intention }\end{array}$ & $\begin{array}{l}\text { Keinginan } \\
\text { konsumen untuk } \\
\text { berperilaku } \\
\text { menurut cara } \\
\text { tertentu dalam } \\
\text { rangka memiliki, } \\
\text { membuang dan } \\
\text { menggunakan } \\
\text { produk atau jasa. } \\
\text { Jadi konsumen } \\
\text { dapat } \\
\text { membentuk } \\
\text { keinginan untuk } \\
\text { mencari } \\
\text { informasi, } \\
\text { memberitahukan } \\
\text { orang lain } \\
\text { tentang } \\
\text { pengalamannya } \\
\text { dengan sebuah } \\
\text { produk, membeli } \\
\text { sebuah produk } \\
\text { atau jasa tertentu. } \\
\text { Variabel ini } \\
\text { diukur dengan } \\
\text { mengunakan } 4 \\
\text { pertanyaan }\end{array}$ & $\begin{array}{l}\text { Skala likert } \\
\text { dengan skala } \\
\text { bobot nilai } \\
\text { dari } 1= \\
\text { sangat tidak } \\
\text { setuju, } 2= \\
\text { tidak setuju, } \\
3=\text { netral, } 4 \\
=\text { setuju dan } \\
5=\text { sangat } \\
\text { setuju. }\end{array}$ & $\begin{array}{l}\text { Carlson } \\
\text { dan } \\
\text { Aron } \\
\text { O'Cass } \\
(2010)\end{array}$ \\
\hline $\begin{array}{l}\text { E-service } \\
\text { Quality }\end{array}$ & $\begin{array}{l}\text { Merupakan } \\
\text { penilaian dan } \\
\text { pertimbangan } \\
\text { konsumen secara } \\
\text { keseluruhan } \\
\text { terhadap } \\
\text { kesempurnaan } \\
\text { dan kualitas } \\
\text { pelayanan dari } \\
\text { suatu bisnis } \\
\text { internet. Variabel } \\
\text { ini diukur dengan } \\
\text { mengunakan } 2 \\
\text { pertanyaan }\end{array}$ & $\begin{array}{l}\text { Skala likert } \\
\text { dengan skala } \\
\text { bobot nilai } \\
\text { dari } 1= \\
\text { sangat tidak } \\
\text { setuju, } 2= \\
\text { tidak setuju, } \\
3=\text { netral, } 4 \\
=\text { setuju dan } \\
5=\text { sangat } \\
\text { setuju. }\end{array}$ & $\begin{array}{l}\text { Jung- } \\
\text { Hwan } \\
\text { Kim dan } \\
\text { Chungho } \\
\text { Kim } \\
(2010)\end{array}$ \\
\hline $\begin{array}{l}\text { Customer } \\
\text { Satisfaction }\end{array}$ & 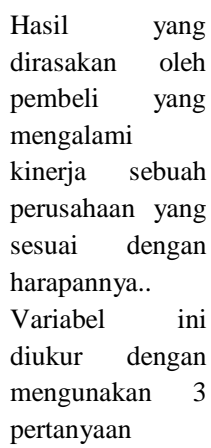 & $\begin{array}{l}\text { Skala likert } \\
\text { dengan skala } \\
\text { bobot nilai } \\
\text { dari } 1= \\
\text { sangat tidak } \\
\text { setuju, } 2= \\
\text { tidak setuju, } \\
3=\text { netral, } 4 \\
=\text { setuju dan } \\
5=\text { sangat } \\
\text { setuju. }\end{array}$ & $\begin{array}{l}\text { Jung- } \\
\text { Hwan } \\
\text { Kim dan } \\
\text { Chungho } \\
\text { Kim } \\
(2010)\end{array}$ \\
\hline $\begin{array}{l}\text { Attitude } \\
\text { Toward the } \\
\text { Website }\end{array}$ & \begin{tabular}{lr}
\multicolumn{2}{l}{ Merupakan sikap } \\
postitf maupun \\
negatif & setiap \\
konsumen & \\
terhadap & suatu \\
situs & web.
\end{tabular} & $\begin{array}{l}\text { Skala likert } \\
\text { dengan skala } \\
\text { bobot nilai } \\
\text { dari } 1= \\
\text { sangat tidak } \\
\text { setuju, } 2=\end{array}$ & $\begin{array}{l}\text { Jamie } \\
\text { Carlson } \\
\text { dan } \\
\text { Aron } \\
\text { O'Cass }\end{array}$ \\
\hline
\end{tabular}




\begin{tabular}{|c|c|c|c|}
\hline & $\begin{array}{lr}\text { Variabel } & \text { ini } \\
\text { diukur dengan } \\
\text { mengunakan } 6 \\
\text { pertanyaan }\end{array}$ & $\begin{array}{l}\text { tidak setuju, } \\
3=\text { netral, } 4 \\
=\text { setuju dan } \\
5=\text { sangat } \\
\text { setuju. }\end{array}$ & (2010) \\
\hline $\begin{array}{l}\text { Brand } \\
\text { Image }\end{array}$ & 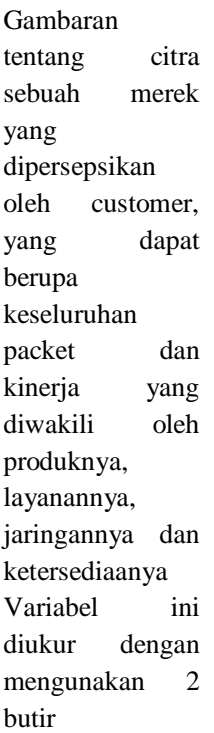 & $\begin{array}{l}\text { Skala likert } \\
\text { dengan skala } \\
\text { bobot nilai } \\
\text { dari } 1= \\
\text { sangat tidak } \\
\text { setuju, } 2= \\
\text { tidak setuju, } \\
3=\text { netral, } 4 \\
=\text { setuju dan } \\
5=\text { sangat } \\
\text { setuju. }\end{array}$ & $\begin{array}{l}\text { Shiau } \\
\text { (2014) }\end{array}$ \\
\hline
\end{tabular}

\begin{tabular}{|c|c|}
\hline Variabel & Indikator \\
\hline $\begin{array}{l}\text { E-service } \\
\text { Quality }\end{array}$ & $\begin{array}{l}\text { 1. Kualitas layanan dari website } \mathrm{x} \text { sempurna } \\
\text { 2. Website } \mathrm{x} \text { memenuhi ekspektasi saya } \\
\text { tentang toko online yang baik }\end{array}$ \\
\hline $\begin{array}{l}\text { Customer } \\
\text { Satisfaction }\end{array}$ & $\begin{array}{l}\text { 1. Saya merasa puas terhadap website } x \\
\text { 2. Saya merasa puas terhadap transaksi } \\
\text { website } x \\
\text { 3. Saya merasa puas terhadap produk dan } \\
\text { pelayanan website } x\end{array}$ \\
\hline & $\begin{array}{l}\text { 1. Saya tidak akan mempertimbangkan } \\
\text { untuk beralih ke website lain } \\
\text { 2. Saya akan membeli barang dari website } x \\
\text { di masa yang akan datang } \\
\text { 3. Saya akan mengunjungi website x pada } \\
\text { masa yang akan datang } \\
\text { 4. Saya akan mengatakan pemikiran yang } \\
\text { positif tentang website } x\end{array}$ \\
\hline $\begin{array}{l}\text { Behavioural } \\
\text { intention }\end{array}$ & $\begin{array}{l}\text { 5. Saya akan merekomendasikan website } \mathrm{x} \\
\text { kepada orang lain }\end{array}$ \\
\hline & $\begin{array}{l}\text { 1. Merek produk memberi perasaan yang } \\
\text { menyenangkan untuk saya }\end{array}$ \\
\hline $\begin{array}{l}\text { Brand } \\
\text { image }\end{array}$ & $\begin{array}{l}\text { 2. Merek produk dapat memenuhi } \\
\text { kebutuhan saya } \\
\text { kenikamatan hidup }\end{array}$ \\
\hline $\begin{array}{l}\text { Attitude } \\
\text { toward the } \\
\text { website }\end{array}$ & $\begin{array}{l}\text { 1. website } \mathrm{x} \text { menarik } \\
\text { 2. Persepsi saya terhadap website } \mathrm{x} \text { adalah } \\
\text { bagus } \\
\text { 3. Ini adalah sebuah website yang bagus } \\
\text { 4. Saya mempunyai pandangan yang baik } \\
\text { terhadap website } \mathrm{x} \\
\text { 5. Saya mempunyai sifat positif yang } \\
\text { mengarah pada website } \mathrm{x} \\
\text { 6. Saya menyukai website } \mathrm{x}\end{array}$ \\
\hline
\end{tabular}

\section{ANALISIS DAN PEMBAHASAN \\ Hasil Uji Kualitas Data \\ Hasil Uji Validitas}

Hasil uji validitas dapat dilihat pada tabel 1 dimana terdapat 16 pertanyaan yang terdiri dari 2 pertanyaan tentang e-service quality, 3 pertanyaan tentang customer satisfaction, 6 pertanyaan tentang attitude toward the website, 2 pertanyaan tentang brand image dan 5 pertanyaan tentang behavioral intention. Dari hasil pengujian, dapat disimpulkan bahwa pertanyaan e-service quality, customer satisfaction, attitude toward the website, brand image dan behavioural intention dinyatakan valid. Oleh karena itu semua pertanyaan tersebut dapat digunakan untuk pengujian berikutnya.

Tabel 1 Hasil Uji Validitas

\begin{tabular}{lcc}
\hline Pertanyaan & Nilai R Pearson & Ket. \\
\hline E service Quality 1 & 0,967 & Valid \\
E service Quality 2 & 0,965 & Valid \\
Customer Satisfaction 1 & 0,830 & Valid \\
Customer Satisfaction 2 & 0,904 & Valid \\
Customer Satisfaction 3 & 0,894 & Valid \\
Attitude 1 & 0,883 & Valid \\
Attitude 2 & 0,868 & Valid \\
Attitude 3 & 0,875 & Valid \\
Attitude 4 & 0,647 & Valid \\
Attitude 5 & 0,717 & Valid \\
Attitude 6 & 0,865 & Valid \\
Brand Image 1 & 0,945 & Valid \\
Brand Image 2 & 0,949 & Valid \\
Behavioural Intention 1 & 0,822 & Valid \\
Behavioural Intention 2 & 0,951 & Valid \\
Behavioural Intention 3 & 0,887 & Valid \\
Behavioural Intention 4 & 0,924 & Valid \\
Behavioural Intention 5 & 0,830 & Valid \\
\hline Sumber: Data primer diolah (2016)
\end{tabular}

Sumber: Data primer diolah (2016)

\section{Hasil Uji Reliabilitas}

Hasil uji reliabilitas menunjukkan bahwa variabel yang diuji reliable karena variabel tersebut memiliki nilai Cronbach's alpha >0,6. Nilai Cronbach's alpha masing-masing variabel dapat dilihat pada tabel 2

Tabel 2 Hasil Uji Reliabilitas

\begin{tabular}{lcc}
\hline Variabel & $\begin{array}{c}\text { Cronbach's } \\
\text { Alpha }\end{array}$ & Ket. \\
\hline E-service quality & 0.928 & Reliabel \\
Consumer satisfaction & 0.845 & Reliabel \\
Attitude towards the & 0.891 & Reliabel \\
website & 0.885 & Reliabel \\
Brand image & 0.928 & Reliabel \\
Behavioral intention & &
\end{tabular}

Sumber: Data primer diolah (2016). 


\section{Hasil Uji Asumsi Klasik}

Pada penelitian ini telah dilakukan uji asumsi klasik dan dari hasilmpenelitianlolos uji asumsi klasik

\section{Hasil Uji Hipotesis \\ Hasil Uji F (F Test)}

Hasil uji $\mathrm{F}$ pada Tabel 3 diperoleh nilai $\mathrm{F}$ hitung untuk analisis regresi pertama antara E-service Quality, dan Brand Image terhadap Customer Satisfaction. Berdasarkan hasil uji F, diperoleh tingkat signifikan sebesar 0,000 . Nilai 0,000 lebih kecil dari 0,05 yang artinya variabel independen berpengaruh secara signifikan terhadap variabel dependen Customer Satisfaction.

Tabel 3 Hasil Uji F E-service Quality dan Brand Image terhadap Customer Satisfaction

\begin{tabular}{lll}
\hline Model & Sig. & Keterangan \\
\hline Regression & $0,000^{\mathrm{a}}$ & Signifikan
\end{tabular}

Sumber: Data primer diolah (2016)

Hasil uji $\mathrm{F}$ pada Tabel 4 diperoleh nilai $\mathrm{F}$ hitung untuk analisis regresi kedua antara E-service Quality, dan Customer Stisfaction terhadap Attitude Toward the Website. Berdasarkan hasil uji $\mathrm{F}$, diperoleh tingkat signifikan sebesar 0,000 . Nilai 0,000 lebih kecil dari 0,05 yang artinya variabel independen berpengaruh secara signifikan terhadap variabel dependen Attitude Toward the Website.

Tabel 4 Hasil Uji F E-service Quality, dan Customer Satisfaction terhadap Attitude Toward the Website

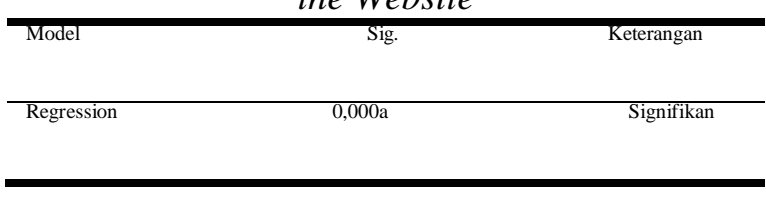

Sumber: Data primer diolah (2016)

Hasil uji $\mathrm{F}$ pada Tabel 5 diperoleh nilai $\mathrm{F}$ hitung untuk analisis regresi ketiga antara Brand Image, Customer Satisfaction, dan Attitude Towards the Website terhadap Behavioural Intention. Berdasarkan hasil uji F, diperoleh tingkat signifikan sebesar 0,000 . Nilai 0,000 lebih kecil dari 0,05 yang artinya semua variabel independen berpengaruh secara signifikan terhadap variabel dependen Behavioural Intention.

Tabel 5 Hasil Uji F Brand Image, Customer Satisfaction dan Attitude Towards the Website terhadap Behavioural Intention

\begin{tabular}{lcc}
\hline Model & Sig. & Keterangan \\
& & \\
\hline Regression & $0,000^{\mathrm{a}}$ & Signifikan
\end{tabular}

Sumber: Data primer diolah (2016)

\section{Hasil Uji t (t Test)}

Berdasarkan hasil uji t pada tabel 4.10 , nilai signifikansi dari variabel e-service quality, dan brand image menunjukkan variabel-variabel tersebut memiliki pengaruh yang signifikan terhadap variabel dependen customer satisfaction, oleh karena itu H1: e-service quality berpengaruh signifikan terhadap customer satisfaction, $\mathrm{H} 2$ : brand image berpengaruh signifikan terhadap customer satisfaction.

Pada hipotesis 1 yang berbunyi e-service quality berpengaruh signifikan terhadap customer satisfaction terbukti. Hal ini di sebabkan bahwa konsumen dalam melakukan pembelian on-line pasti memperhatikan menampilkan website yang menarik dan kemudahan penggunaan (ease of use) untuk navigasi merupakan hal penting yang mempengaruhi customer satisfaction Apabila menampilkan website tidak menarik dan susah untuk melakukan aplikasi pembelian maka konsumen akan mencari online shop yang lain. E-service quality sebagai penilaian konsumen terhadap kualitas pelayanan secara keseluruhan dari suatu bisnis internet. E-service quality sebagai kemampuan suatu situs untuk menyediakan bantuan untuk berbelanja secara efisien dan efektif, ketika melakukan pembelian dan ketika menyampaikan produk dan jasa. $S$ service quality sebagai suatu batasan dimana suatu website menyediakan fasilitas belanja, pembelian, produk dan pelayanan jasa secara efisien dan efektif.

Pada hipotesis 2 terbukti bahwa brand image berpengaruh terhadap kepuasan konsumen. Hal ini bisa terjadi karena brand Image adalah sejumlah keyakinan tentang merek. Brand image atau citra merek muncul berdasarkan keyakinan konsumen terhadap suatu merek tertentu baik secara fungsional maupun simbolis. Pemahaman brand image secara lebih baik, hendaknya memperhatikan karakteristik yang unik dari suatu produk dan melihat apa saja yang menjadi faktor penentu kepuasan 
pelanggan. Hasil evaluasi terhadap suatu brand image dipilih memenuhi atau melampaui ekspektasinya, maka pelanggan tersebut akan menunjukkan sikap positif, dan memiliki keinginan untuk membeli/menggunakan kembali. keinginannya untuk bertindak sebagai referensi bagi orang lain (advocacy intentions). Intinya bahwa kepuasan pelanggan akan memainkan peran penting dalam menjelaskan alasan pelanggan dipandang loyal.

Tabel 6 Hasil Uji t E-service Quality dan Brand Image terhadap Customer Satisfaction

\begin{tabular}{lll}
\hline Model & Sig. & Kesimpulan \\
\hline Konstanta & 0,000 & \\
E-service Quality & 0,000 & H1 Signifikan \\
Brand Image & 0,000 & H2 Signifikan
\end{tabular}

a. Dependent Variable: Customer Satisfaction Sumber: Data primer diolah (2016)

Berdasarkan hasil uji t pada tabel 6 nilai signifikansi dari variabel e-service quality, dan customer satisfaction menunjukkan variabelvariabel tersebut memiliki pengaruh yang signifikan terhadap variabel dependen attitude towards the website, oleh karena itu $\mathrm{H} 3$ : eservice quality berpengaruh signifikan terhadap attitude towards the website, $\mathrm{H} 4$ : customer satisfaction berpengaruh signifikan terhadap attitude towards the website.

Pada Hipotesis 3 terbukti bahwa e-service quality berpengaruh signifikan terhadap attitude towards the website. Hal ini di karenakan Sikap atau Attitude merupakan tanggapan yang timbul sebagai akibat, melihat, merasakan dan mengetahui tentang sesuatu. Sikap ini dapat mengarah pada arah yang baik ataupun sebaliknya terhadap suatu objek yang cenderung muncul secara konsisten dan sikap cenderung konsisten daripada perilaku atau behavior. Attitude sebagai dorongan psikologi yang ditunjukkan dengan menilai seberapa tinggi rasa suka atau ketidaksukaan seseorang terhadap sesuatu. Penilaian seseorang secara keseluruhan terhadap suatu konsep, dimana diasumsikan semakin positf penilaian seseorang terhadap suatu produk/merek maka semakin tinggi kemungkinan seseorang akan membeli atau menggunakannya. apabila suatu web memperhatikan menampilkan website yang menarik dan kemudahan penggunaan (ease of use) untuk navigasi merupakan hal penting yang mempengaruhi attitude Apabila menampilkan website tidak menarik dan susah untuk melakukan aplikasi pembelian maka konsumen akan mencari online shop yang lain. E-service quality sebagai penilaian konsumen terhadap kualitas pelayanan secara keseluruhan dari suatu bisnis internet. E-service quality sebagai kemampuan suatu situs untuk menyediakan bantuan untuk berbelanja secara efisien dan efektif, ketika melakukan pembelian dan ketika menyampaikan produk dan jasa. S-service quality sebagai suatu batasan dimana suatu website menyediakan fasilitas belanja, pembelian, produk dan pelayanan jasa secara efisien dan efektif.

Pada Hipoteis 4 terbukti bahwa customer satisfaction berpengaruh signifikan terhadap attitude towards the website. Hal ini di karenakan apabila konsumen merasa puas akan berdampak pada sikap konsumen terhadap suatu web site. Dampak dari kepuasan konsumen sangat banyak salah satunya adalah bisa mempengaruhi Attitude konsumen terhadap web site tertentu. sikap merupakan ekspresi perasaan yang berasal dari dalam diri individu yang mencerminkan apakah seseorang senang atau tidak senang, suka atau tidak suka dan setuju atau tidak setuju terhadap suatu objek. sikap adalah suatu predisposisi yang dipelajari untuk merespon terhadap suatu obyek dalam bentuk rasa suka atau tidak suka. Sikap terhadap perilaku didefinisikan sebagai individu positif atau negatif perasaan tentang melakukan perilaku sasaran.

Tabel 7 Hasil Uji t E-service Quality dan Customer Satisfaction terhadap Attitude Towards the Website

\begin{tabular}{lcc}
\hline Model & Sig. & Kesimpulan \\
\hline Konstanta & 0,000 & \\
E-service Quality & 0,000 & H3 Signifikan \\
Customer Satisfaction & 0,000 & H4 Signifikan
\end{tabular}

b. Dependent Variable: Attitude Towards the Website Sumber: Data primer diolah (2016)

Berdasarkan hasil uji $\mathrm{t}$ pada tabel 7 , nilai signifikansi dari variabel brand image, customer satisfaction, dan attitude towards the website 
menunjukkan variabel-variabel tersebut memiliki pengaruh yang signifikan terhadap variabel dependen behavioural intention, oleh karena itu H5: brand image berpengaruh signifikan terhadap behavioural intention, H6: customer satisfaction berpengaruh signifikan terhadap behavioural intention, $\mathrm{H} 7$ : attitude towards the website berpengaruh signifikan terhadap behavioural intention.

Pada Hipotesis 5 terbukti bahwa brand image berpengaruh signifikan terhadap behavioural intention. Tidak mudah untuk membentuk image, sehingga bila terbentuk sulit untuk mengubahnya. Brand Image adalah representasi dari keseluruhan persepsi terhadap merek dan dibentuk dari informasi dan pengalaman masa lalu terhadap merek itu. Konsumen yang memiliki citra yang positif terhadap suatu merek, akan lebih memungkinkan untuk melakukan pembelian. Pembelian produk pada masa kini banyak dipengaruhi oleh Brand image yang yang secara langsung akan mempengaruhi behavioural intention. Brand image yang kuat tidak hanya meningkatkan diferensiasi antara pesaing, tetapi juga memperkuat kepercayaan, dan mempunyai hubungan yang positif terhadap perilaku pelanggan, meminimalkan risiko yang dirasakan, dan merupakan kualitas tinggi dari titik pandang pelanggan brand image tergantung pada penciptaan tingginya tingkat kesadaran merek Brand Image memiliki hubungan terhadap perilaku konsumen dalam membeli suatu barang, terutama di mana konsumen sulit untuk membedakan produk atau jasa berdasarkan atribut tidak berwujud. Ini juga menyarankan bahwa brand image meningkatkan keunggulan kompetitif merek.

Pada Hipotesis 6 terbukti bahwa customer satisfaction berpengaruh signifikan terhadap behavioural intention. Custumer satisfaction merupakan suatu reaksi yang cenderung muncul setelah suatu pelayanan diberikan. Customer satisfaction merupakan suatu keadaan konsumen terhadap suatu jasa, apakah suatu jasa telah memenuhi kebutuhan dan ekspektasi dari konsumen. Customer satisfaction adalah respon dari konsumen yang merasa kebutuhannya terpenuhi dan merupakan penilaian apakah fitur suatu produk atau jasa ataupun produk itu sendiri mampu memenuhi tingkat kebutuhan konsumsi sesuai dengan yang diinginkan konsumen ataupun melebihi dari apa yang diharapkan. Pelanggan website yang puas cenderung akan berkunjung kembali, melakukan pembelian, dan merekomendasikan website tersebut. Konsumen yang tidak puas cenderung mencari informasi tentang website alternatif yang lain, lebih setia terhadap website kompetitor dan menolak untuk membangun hubungan yang lebih dekat dengan website yang tersebut. Customer satisfaction merupakan penyebab utama terjadinya pengulanggan perilaku pembelian (repeat purchase behaviour). Customer satisfaction secara keseluruhan dari suatu produk maupun jasa memiliki kaitan yang kuat dengan behavioural intention. Satisfaction mempengaruhi niat konsumen untuk mengulangi pembelian barang atau penggunaan jasa. Bahwa untuk meningkatkan customer satisfaction merupakan hal penting untuk memicu munculnya niat konsumen untuk berkunjung kembali (revisit intention) dan merekomendasikan retailer ke pelanggan lainnya.

Pada Hipotesis 7 terbukti bahwa attitude towards the website berpengaruh signifikan terhadap behavioural intention. sikap (attitude) yang positif akan menghasilkan perilaku (behavior) yang positif juga karena adanya keterkaitan antara perilaku dengan sikap seseorang terhadap suatu objek. Sikap positif pengguna terhadap situs (attitude toward the website) akan menyebabkan konsumen berkeinginan untuk menggunakan dan membeli kembali dari situs tersebut (behavior intention). Sikap merupakan ekspresi perasaan yang berasal dari dalam diri individu yang mencerminkan apakah seseorang senang atau tidak senang, suka atau tidak suka dan setuju atau tidak setuju terhadap suatu website. sikap adalah suatu predisposisi yang dipelajari untuk merespon terhadap suatu website dalam bentuk rasa suka atau tidak suka. Sikap terhadap perilaku didefinisikan sebagai individu positif atau negative perasaan tentang melakukan perilaku sasaran. Attitude ini dapat dibentuk dari pengalaman, pembelajaran dan proses di masa lalu dan sekarang yang membentuk nilai dan norma terhadap sesuatu. Proses ini dibentuk melalui pemikiran kognitif, afektif dan konatif yang pada akhirnya dapat membentuk pola atau kebiasaan pada diri seorang pelanggan. Sikap yang baik pelanggan pada sebuah website banyak dipengaruhi oleh easy to use, praktis, dan memberi nilai prestise pada pelanggan. Hasil penelitian terdapat pengaruh attitude terhadap behavioral intention. Sikap terhadap website internet merupakan modal awal bagi pelanggan untuk terus atau tidak meneruskan untuk 
melakukan transaksi menggunakan teknologi. Pelanggan yang menyukai kepraktisan lebih senang menggunakan peralatan elektornik untuk bertransaksi, sepanjang kinerja website memiliki nilai yang sebanding dengan harapan pelanggan ketika berinteraksi didalamnya. Easy to use dan efficiency adalah bagian utama dalam nilai kesukaan pelanggan menggunakan website untuk melanjutkan transaksinya. Penelitian ini menunjukkan bahwa sikap yang baik terhadap sebuah website memberi daya picu terhadap niat untuk melakukan aktivitas atau bertransaksi pada diri pelanggan. Sikap pelanggan yang baik terhadap website banyak dibentuk oleh pengalaman dan proses belajar saat menggunakan fasilitas yang ada pada website tersebut atau fitur-fitur yang ada.

Tabel 8 Hasil Uji T Brand Image, Customer Satisfaction, dan Attitude towards the website terhadap Behavioural Intention

\begin{tabular}{lll}
\hline Model & Sig. & Kesimpulan \\
\hline Brand image & 0,004 & H5 Signifikan \\
$\begin{array}{l}\text { Customer } \\
\text { Satisfaction }\end{array}$ & 0,000 & H6 Signifikan \\
$\begin{array}{l}\text { Attitude Towards } \\
\text { the Website }\end{array}$ & 0,000 & H7 Signifikan \\
\hline
\end{tabular}

Sumber: Data primer diolah (2016)

\section{Hasil Uji Koefisien Korelasi (R) dan Koefisien Determinasi $\left(\mathbf{R}^{2}\right)$}

Berdasarkan tabel 9 diperoleh hasil uji koefisien korelasi (R) diperoleh nilai koefisien korelasi sebesar 0,864 yang berarti variabel e-service quality, dan brand image memiliki hubungan dengan variabel customer satisfaction sebesar $86,4 \%$.

Nilai adjusted $\mathrm{R}^{2}$ sebesar 0,744 dari hasil uji tabel 4.13 dapat diperoleh hasil bahwa variabel customer satisfaction dapat dijelaskan oleh variabel $e$-service quality, dan brand image sebesar 74,4\% sedangkan sisa $25,6 \%$ dijelaskan oleh variabel lain yang tidak terdapat pada model.
Tabel 9 Hasil Uji Koefisien Korelasi (R) dan

Koefisien Determinasi Adjusted $\mathrm{R}^{2}$

E-service Quality dan Brand Image terhadap Customer Satisfaction

\begin{tabular}{lcc}
\hline $\mathbf{R}$ & $\mathbf{R}$ Square & Adjusted $\boldsymbol{R}$ Square \\
\hline 0,864 & 0,746 & 0,744
\end{tabular}

Sumber: Data primer diolah (2016)

Berdasarkan tabel 10 diperoleh hasil uji koefisien korelasi (R) diperoleh nilai koefisien korelasi sebesar 0,876 yang berarti variabel e-service quality, dan customer satisfaction memiliki hubungan dengan variabel attitude towards the website sebesar $87,6 \%$.

Nilai adjusted $\mathrm{R}^{2}$ sebesar 0,767 dari hasil uji tabel 4.14 dapat diperoleh hasil bahwa variabel attitude towards the website dapat dijelaskan oleh variabel e-service quality, dan customer satisfaction sebesar $76,7 \%$ sedangkan sisa $23,3 \%$ dijelaskan oleh variabel lain yang tidak terdapat pada model.

Tabel 10 Hasil Uji Koefisien Korelasi (R) dan Koefisien Determinasi Adjusted $\mathrm{R}^{2}$

E-service Quality dan Customer Satisfaction terhadap Attitude Towards the Website

\begin{tabular}{llc}
\hline $\mathbf{R}$ & R Square & Adjusted $\boldsymbol{R}$ Square \\
\hline 0,876 & 0,768 & 0,767
\end{tabular}

Sumber: Data primer diolah (2016)

Berdasarkan tabel 11 diperoleh hasil uji koefisien korelasi (R) diperoleh nilai koefisien korelasi sebesar 0,963 yang berarti variabel brand image, customer satisfaction, dan attitude towards the website memiliki hubungan dengan variabel behavioural intention sebesar 96,3\%.

Nilai adjusted $\mathrm{R}^{2}$ sebesar 0,927 dari hasil uji tabel 4.15 dapat diperoleh hasil bahwa variabel behavioural intention dapat dijelaskan oleh variabel brand image, customer satisfaction, dan attitude towards the website sebesar 92,7\% sedangkan sisa 7,3\% dijelaskan oleh variabel lain yang tidak terdapat pada model. 
Tabel 11 Hasil Uji Koefisien Korelasi (R) dan Koefisien Determinasi Adjusted $\mathrm{R}^{2}$

Brand Image, Customer Satisfaction dan Attitude Towards the Website terhadap Behavioural Intention

\begin{tabular}{lcc}
\hline R & R Square & Adjusted R Square \\
\hline 0,963 & 0,927 & 0,927
\end{tabular}

Sumber: Data primer diolah (2016)

\section{KESIMPULAN, KETERBATASAN DAN REKOMENDASI \\ Kesimpulan}

Pada hipotesis 1 yang berbunyi e-service quality berpengaruh signifikan terhadap customer satisfaction terbukti. Hal ini di sebabkan bahwa konsumen dalam melakukan pembelian on-line pasti memperhatikan menampilkan website yang menarik dan kemudahan penggunaan (ease of use) untuk navigasi merupakan hal penting yang mempengaruhi customer satisfaction Apabila menampilkan website tidak menarik dan susah untuk melakukan aplikasi pembelian maka konsumen akan mencari online shop yang lain. E-service quality sebagai penilaian konsumen terhadap kualitas pelayanan secara keseluruhan dari suatu bisnis internet. E-service quality sebagai kemampuan suatu situs untuk menyediakan bantuan untuk berbelanja secara efisien dan efektif, ketika melakukan pembelian dan ketika menyampaikan produk dan jasa. $S$ service quality sebagai suatu batasan dimana suatu website menyediakan fasilitas belanja, pembelian, produk dan pelayanan jasa secara efisien dan efektif. Hasil penelitian e-service konsisten dengan penelitian yang dilakukan oleh, Kim dan Stoel, (2004), Collier dan Bienstock (2006), Cristobal et al. (2007), Saif, I.M, (2009), Carlson dan O'Cass (2010), Petzer dan De Meyer (2011).

Pada hipotesis 2 terbukti bahwa brand image berpengaruh terhadap kepuasan konsumen. Hal ini bisa terjadi karena brand Image adalah sejumlah keyakinan tentang merek. Brand image atau citra merek muncul berdasarkan keyakinan konsumen terhadap suatu merek tertentu baik secara fungsional maupun simbolis. Pemahaman brand image secara lebih baik, hendaknya memperhatikan karakteristik yang unik dari suatu produk dan melihat apa saja yang menjadi faktor penentu kepuasan pelanggan. Hasil evaluasi terhadap suatu brand image dipilih memenuhi atau melampaui ekspektasinya, maka pelanggan tersebut akan menunjukkan sikap positif, dan memiliki keinginan untuk membeli/menggunakan kembali. keinginannya untuk bertindak sebagai referensi bagi orang lain (advocacy intentions). Intinya bahwa kepuasan pelanggan akan memainkan peran penting dalam menjelaskan alasan pelanggan dipandang loyal. Hasil penelitian ini konsisten dengan penelitian yang dilakukan oleh, Carlson dan O'Cass (2010), Erni, K. M.S dan Heru, P (2012), Vijayasarathy, (2004).

Hipotesis 3 terbukti bahwa e-service quality berpengaruh signifikan terhadap attitude towards the website. Hal ini di karenakan Sikap atau Attitude merupakan tanggapan yang timbul sebagai akibat, melihat, merasakan dan mengetahui tentang sesuatu. Sikap ini dapat mengarah pada arah yang baik ataupun sebaliknya terhadap suatu objek yang cenderung muncul secara konsisten dan sikap cenderung konsisten daripada perilaku atau behavior. Attitude sebagai dorongan psikologi yang ditunjukkan dengan menilai seberapa tinggi rasa suka atau ketidaksukaan seseorang terhadap sesuatu. Penilaian seseorang secara keseluruhan terhadap suatu konsep, dimana diasumsikan semakin positf penilaian seseorang terhadap suatu produk/merek maka semakin tinggi kemungkinan seseorang akan membeli atau menggunakannya. apabila suatu web memperhatikan menampilkan website yang menarik dan kemudahan penggunaan (ease of use) untuk navigasi merupakan hal penting yang mempengaruhi attitude Apabila menampilkan website tidak menarik dan susah untuk melakukan aplikasi pembelian maka konsumen akan mencari online shop yang lain. E-service quality sebagai penilaian konsumen terhadap kualitas pelayanan secara keseluruhan dari suatu bisnis internet. E-service quality sebagai kemampuan suatu situs untuk menyediakan bantuan untuk berbelanja secara efisien dan efektif, ketika melakukan pembelian dan ketika menyampaikan produk dan jasa. S-service quality sebagai suatu batasan dimana suatu website menyediakan fasilitas belanja, pembelian, produk dan pelayanan jasa secara efisien dan efektif. Hasil penelitian ini konsisten dengan penelitian yang dilakukan oleh, Yi dan La (2004).

Pada Hipoteis 4 terbukti bahwa customer satisfaction berpengaruh signifikan terhadap attitude towards the website. Hal ini di karenakan apabila konsumen merasa puas akan berdampak pada sikap konsumen terhadap suatu 
web site. Dampak dari kepuasan konsumen sangat banyak salah satunya adalah bisa mempengaruhi Attitude konsumen terhadap web site tertentu. sikap merupakan ekspresi perasaan yang berasal dari dalam diri individu yang mencerminkan apakah seseorang senang atau tidak senang, suka atau tidak suka dan setuju atau tidak setuju terhadap suatu objek. sikap adalah suatu predisposisi yang dipelajari untuk merespon terhadap suatu obyek dalam bentuk rasa suka atau tidak suka. Sikap terhadap perilaku didefinisikan sebagai individu positif atau negative perasaan tentang melakukan perilaku sasaran. Hasil penelitian ini konsisten dengan penelitian yang dilakukan oleh, Pappu dan cooksay (2005), Sniehotta et al. (2005), Khan et al. (2012), Majeed (2012).

Pada Hipotesis 5 terbukti bahwa brand image berpengaruh signifikan terhadap behavioural intention. Tidak mudah untuk membentuk image, sehingga bila terbentuk sulit untuk mengubahnya. Brand Image adalah representasi dari keseluruhan persepsi terhadap merek dan dibentuk dari informasi dan pengalaman masa lalu terhadap merek itu. Konsumen yang memiliki citra yang positif terhadap suatu merek, akan lebih memungkinkan untuk melakukan pembelian. Pembelian produk pada masa kini banyak dipengaruhi oleh Brand image yang yang secara langsung akan mempengaruhi behavioural intention. Brand image yang kuat tidak hanya meningkatkan diferensiasi antara pesaing, tetapi juga memperkuat kepercayaan, dan mempunyai hubungan yang positif terhadap perilaku pelanggan, meminimalkan risiko yang dirasakan, dan merupakan kualitas tinggi dari titik pandang pelanggan brand image tergantung pada penciptaan tingginya tingkat kesadaran merek Brand Image memiliki hubungan terhadap perilaku konsumen dalam membeli suatu barang, terutama di mana konsumen sulit untuk membedakan produk atau jasa berdasarkan atribut tidak berwujud. Ini juga menyarankan bahwa brand image meningkatkan keunggulan kompetitif merek. Hasil penelitian ini konsisten dengan penelitian yang dilakukan oleh Carlson dan O'Cass (2010), Mosavi dan Ghaedi (2011).

Pada Hipotesis 6 terbukti bahwa customer satisfaction berpengaruh signifikan terhadap behavioural intention. Custumer satisfaction merupakan suatu reaksi yang cenderung muncul setelah suatu pelayanan diberikan. Customer satisfaction merupakan suatu keadaan konsumen terhadap suatu jasa, apakah suatu jasa telah memenuhi kebutuhan dan ekspektasi dari konsumen. Customer satisfaction adalah respon dari konsumen yang merasa kebutuhannya terpenuhi dan merupakan penilaian apakah fitur suatu produk atau jasa ataupun produk itu sendiri mampu memenuhi tingkat kebutuhan konsumsi sesuai dengan yang diinginkan konsumen ataupun melebihi dari apa yang diharapkan. Pelanggan website yang puas cenderung akan berkunjung kembali, melakukan pembelian, dan merekomendasikan website tersebut. Konsumen yang tidak puas cenderung mencari informasi tentang website alternatif yang lain, lebih setia terhadap website kompetitor dan menolak untuk membangun hubungan yang lebih dekat dengan website yang tersebut. Customer satisfaction merupakan penyebab utama terjadinya pengulanggan perilaku pembelian (repeat purchase behaviour). Customer satisfaction secara keseluruhan dari suatu produk maupun jasa memiliki kaitan yang kuat dengan behavioural intention. Satisfaction mempengaruhi niat konsumen untuk mengulangi pembelian barang atau penggunaan jasa. Bahwa untuk meningkatkan customer satisfaction merupakan hal penting untuk memicu munculnya niat konsumen untuk berkunjung kembali (revisit intention) dan merekomendasikan retailer ke pelanggan lainnya. Hasil penelitian ini konsisten dengan penelitian yang dilakukan oleh Schiffman et al. (2008), Lien, et al. (2011), Erni, K. M.S dan Heru, P (2012), Chang et al., (2009), Hu et al., (2009), Kouthouris dan Alexandris, (2005), Tam (2004), Kanuk (2003).

Pada Hipotesis 7 terbukti bahwa attitude towards the website berpengaruh signifikan terhadap behavioural intention. sikap (attitude) yang positif akan menghasilkan perilaku (behavior) yang positif juga karena adanya keterkaitan antara perilaku dengan sikap seseorang terhadap suatu objek. Sikap positif pengguna terhadap situs (attitude toward the website) akan menyebabkan konsumen berkeinginan untuk menggunakan dan membeli kembali dari situs tersebut (behavior intention). Sikap merupakan ekspresi perasaan yang berasal dari dalam diri individu yang mencerminkan apakah seseorang senang atau tidak senang, suka atau tidak suka dan setuju atau tidak setuju terhadap suatu website. sikap adalah suatu predisposisi yang dipelajari untuk merespon terhadap suatu website dalam bentuk rasa suka atau tidak suka. Sikap terhadap perilaku didefinisikan sebagai individu positif atau 
negative perasaan tentang melakukan perilaku sasaran. Attitude ini dapat dibentuk dari pengalaman, pembelajaran dan proses di masa lalu dan sekarang yang membentuk nilai dan norma terhadap sesuatu. Proses ini dibentuk melalui pemikiran kognitif , afektif dan konatif yang pada akhirnya dapat membentuk pola atau kebiasaan pada diri seorang pelanggan. Sikap yang baik pelanggan pada sebuah website banyak dipengaruhi oleh easy to use, praktis, dan memberi nilai prestise pada pelanggan. Hasil penelitian terdapat pengaruh attitude terhadap behavioral intention. Sikap terhadap website internet merupakan modal awal bagi pelanggan untuk terus atau tidak meneruskan untuk melakukan transaksi menggunakan teknologi. Pelanggan yang menyukai kepraktisan lebih senang menggunakan peralatan elektornik untuk bertransaksi, sepanjang kinerja website memiliki nilai yang sebanding dengan harapan pelanggan ketika berinteraksi didalamnya. Easy to use dan efficiency adalah bagian utama dalam nilai kesukaan pelanggan menggunakan website untuk melanjutkan transaksinya. Penelitian ini menunjukkan bahwa sikap yang baik terhadap sebuah website memberi daya picu terhadap niat untuk melakukan aktivitas atau bertransaksi pada diri pelanggan. Sikap pelanggan yang baik terhadap website banyak dibentuk oleh pengalaman dan proses belajar saat menggunakan fasilitas yang ada pada website tersebut atau fitur-fitur yang ada. Hasil pengujian hipotesis ketujuh dengan regresi sederhana memperoleh hasil bahwa variable attitude towards the website memiliki pengaruh yang signifikan terhadap behavioural intention. Hasil penelitian ini konsisten dengan penelitian yang dilakukan oleh Vijayasarathy (2004), Carlson dan O'Cass (2010), Mosavi dan Ghaedi (2011), Seock (2007)

\section{Keterbatasan}

Adapun keterbatasan dalam penelitian ini adalah sebagai berikut:

1. Keterbatasan yang melekat pada diri peneliti, dimana peneliti tidak dapat mengontrol jawaban responden secara langsung sehingga hal ini bisa saja responden tidak jujur dalam memberi jawaban.

2. Sampel penelitian yang digunakan dalam penelitian ini adalah para mahasiswa dan mahasiswi pelanggan toko online di kota Batam sehingga jika penelitian yang sama diterapkan dengan menggunakan sampel penelitian yang berbeda belum tentu akan memperoleh hasil yang sama dengan penelitian terdahulu.

\section{Rekomendasi}

Adapun rekomendasi penulis bagi perusahaan adalah sebagai berikut:

1. Menggunakan jenis sampel penelitian yang berbeda dari yang digunakan di penelitian terdahulu untuk menyempurnakan hasil penelitian.

2. Bagi Online shop :

a. Online shop harus memberikan perhatian khusus kepada konsumen

Mempromosikan bisnis toko online di sosial media, sebaiknya jangan hanya fokus memikirkan posting iklan produk. Sebab, keterikatan dengan para konsumen turut serta membesarkan brand produk Anda. Oleh karena itu, beri ruang khusus bagi para konsumen agar mereka bisa membangun komunikasi dua arah dengan Anda, selain itu Anda juga bisa melibatkan mereka dalam mempromosikan produk-produk Anda. Karena hal ini akan membentuk brand image

b. Berikan Postingan yang Bermanfaat Bagi Konsumen

Mengingat akun Anda mengusung nama baik dari brand produk yang dipasarkan, maka sebelum memposting sesuatu di akun tersebut sebaiknya pikirkan dengan matang nilai tambah yang Anda berikan bagi para konsumen. Dalam hal ini Anda bisa berbagi informasi menarik seputar bisnis Anda, memberikan tips dan trik yang bermanfaat bagi para konsumen, serta bisa juga membuka peluang kerjasama bagi para konsumen yang tertarik menjadi reseller produk Anda. Dengan begitu, para konsumen bisa lebih mengenal produk Anda dan tidak menutup kemungkinan bisa lebih loyal dengan perusahaan Anda. 
c. Apapun Kondisinya Katakan dengan Jujur pada Konsumen Anda

Untuk mendatangkan omzet yang cukup besar, tak jarang sebagian pelaku bisnis toko online melakukan kecurangan untuk menarik minat konsumen. Tentu tindakan seperti ini tidak kami rekomendasikan, karena hanya akan merusak citra baik produk Anda dan menghilangkan kepercayaan dari para konsumen. Karena itu, pastikan bila Anda selalu mengatakan kondisi yang sejujurnya kepada para konsumen Anda, dan sampaikan dengan cara yang baik agar mereka bisa menerima ketidaknyamanan tersebut dengan respon yang positif.

d. Desain lah web site dengan lebih menarik dan easy to use.

Konsuemn akan lebih suka menggunakan website yang mudah penggunakaannya dari pada web site yang rumit. Pelanggan yang menyukai kepraktisan lebih senang menggunakan peralatan elektornik untuk bertransaksi, sepanjang kinerja website memiliki nilai yang sebanding dengan harapan pelanggan ketika berinteraksi didalamnya. Easy to use dan efficiency adalah bagian utama dalam nilai kesukaan pelanggan menggunakan website untuk melanjutkan transaksinya.

e. Bukalah no telpon layanan pelanggan agar pelanggan dapat menghubungi online shop tersebut. Hal ini di perlukan apabila konsumen ingin melacak pesanan dan order dari konsumen. Layanan ini juga bermanfaat untuk konsumen melakukan kompain atau tidak puas terhadap layanan dari online shop.

3. Menambahkan variabel-variabel lain yang tidak terdapat pada model penelitian ini akan tetapi berpengaruh terhadap variabel customer satisfaction, attitude towards the website dan behavioural intention, seperti interaction orientation Liang dan Zhang (2011), monetary value, convenience value dan epistemic value Mosavi dan Ghaedi (2011), perceived value Lien, Wen, dan Wu (2011), process quality, outcome quality, dan recovery Collier dan Bienstock (2006). Oleh karena itu, untuk penelitian yang akan datang perlu dilakukan penambahan variabelvariabel lainnya untuk menyempurnakan model penelitian.

\section{DAFTAR PUSTAKA}

Bansal, H., McDougall, G., Dikolli, S. \& Sedatole, K. (2004), "Relating esatisfaction to behavioral outcomes", Journal of Services Marketing, Vol. 18 No. 4, pp. 290-302.

Carlson, J \& Aron O'Cass, A. (2010). "Exploring the relationshipd between e-service quality, satisfaction, attitudes and behaviours in contentdriven e-service web sites". Journal of service marketing, Vol. 24 No. 2, pp. 112-127.

Chang, H.H., Wang, Y.H., \& Yang, W.Y. (2009). The Impact of E-Service Quality, Satisfaction, and Loyalty on E-Marketing: Moderating Effect of Perceived Value. Total Quality Management, 20(4), 423-443.

Cai, S. (2009). The importance of customer focus for organizational performance: a study of Chinese companies, International Journal of Quality \& Reliability Management, Vol. 26 No. 4, pp. 369-79.

Chang, H.H., Wang, Y.H., Yang, W.Y. (2009) The Impact of E-Service Quality, Satisfaction, and Loyalty on E-Marketing: Moderating Effect of Perceived Value. Total Quality Management, 20(4), 423-443.

Collier, J.E. \& Bienstock, C.C. (2006), "Measuring service quality in eretailing", Journal of Service 
Research, Vol. 8 No. 3, pp. 26075.

Cristobal, E., Flavian, C. \& Guinaliu, M. (2007). Perceived e-service quality (PeSQ): measurement validation and effects on consumer satisfaction and web site loyalty, Managing Service Quality, Vol. 17 No. 3, pp. 317-40.

Dagger, Trecey \& Sweeney (2006). The effect of service evaluation on behavioral intentions and qualityof-life." Journal of service research, 9(1)2-19.

Griffin, D. \& O'Cass, A. (2004), Exploring anti-smoking and antibinge drinking issues in the context of generally accepted consumer theory. Journal of Nonprofit and Public Sector Marketing, Vol. 12 No. 2, pp. 10527.

Hansenmark, Ove C. \& Marie Albinsson. (2004). Customer Satisfaction and Retention: The Experiences of Individual Employees. Managing Service Quality, 14 (1), 40-57.

Han, H., \& Ryu, K. (2006). Moderating role of personal characteristics in forming restaurant customers' behavioral intentions - An upscale restaurant setting. Journal of Hospitality \& Leisure Marketing, 15(4).

Hu, H.H., Kandampully, J., \& Juwaheer, T.D. (2009). Relationships and Impacts of Service Quality, Perceived Value, Satisfaction, and Image: An Empirical Study. The Service Industries Journal, 29(2), 111-25.

Jamie Carlson \& Aron O'Cass (2010) Exploring the Relationship between e-service quality, satifaction, attitude and behaviours in conten-driven e-servoce web site, Journal of services Marketing, vol 24, Issue 2. Pp. 112-127
Jung-Hwan Kim \& Chungho. ( 2010). E-Service Quality Perceptions : Cross-cultural, Comparison of America and Korean Consumer's, Journal of Research in interactive Marketing, Vol 4 Issue 3, pp 257 275

Kim, S. \& Stoel, L. (2004). Apparel retailers: web site quality and satisfaction. Journal of Retailing and Consumer Services, Vol. 11 No. 2, pp. 109-17.

Kouthouris, C., \& Alexandris, K. (2005). Can Service Quality Predict Customer Satisfaction and Behavioral Intentions in the Sport Tourism Industry? An Application of the SERVQUAL Model in an Outdoor Setting. Journal of Sport Tourism, 10(2), 101-111.

Lu Y, \& Seock Y.K. (2007). The influence of grey consumers' service quality perceptions on satisfaction and store loyalty behaviour. Int. J. Retail Distrib. Manage., 36(11): 901-918.

Namkung, Y. \& Jang, S. (2007). Does food quality really matter in restaurant?: its impact on customer satisfaction and behavioral intentions. Journal of Hospitality and Tourism Research, Vol. 31 No. 3, pp. 387-410.

O'Cass, A. \& Grace, D. (2004), "Exploring consumer experiences with a service brand", Journal of Product \& Brand Management, Vol. 13 No. 4, pp. 257-68.

Parasuraman, A., Zeithaml, V.A. \& Malhotra, A. (2005), "E-S-QUAL: a multiple-item scale for assessing electronic service quality", Journal of Service Research, Vol. 7 No. 3, pp. 213-33.

Rowley, J. (2006). An Analysis of the Eservice Literature: Towards a Research Agenda. Internet Research, 16(3), 339-59.

Saha GC, \& Theingi H. (2009). Service quality, satisfaction, and 
behavioral intentions: a study of low-cost airline carriers in Thailand. Manage. Serv.. Qual., 19(3): 350-372.

Shiau. (2014). The Impact of Prduct Innovation on Behavior Intention: The Measurement of the Mediating Effect of the brand Image of Japanese Anime Dolls.

Tam, L.M. (2004). Customer Satisfaction, Service Quality and Perceived Value: An Integrative Model. Journal of Marketing Management, 20, 897-917.

Vijayasarathy, L. (2004). Predicting consumer intentions to use online shopping: the case for an augmented technology acceptance model. Information and Management, Vol. 41 No. 6, pp. 747-62.

Wong, A. \& Sohal, A.S. (2006), "Understanding the quality of relationships in consumer services: a study in a retail environment", International Journal of Quality \& Reliability Management, Vol. 23 Nos 2/3, pp. 244-64.

Yang, Z. \& Fang, X. (2004), "Online service quality dimensions and their relationships with satisfaction: a content analysis of customer review of securities brokerage services", International Journal of Service Industry Management, Vol. 15 No. 3, pp. 302-26.

Yen, C.-H. and Lu, H.-P. (2008). Effects of e-service quality on loyalty intention: an empirical study in online auction. Managing Service Quality, Vol. 18 No. 2, pp. 12746.

$\mathrm{Yu}$, C.H., Chang, H.C., Huang, G.L. (2006). A Study of Service Quality, Customer Satisfaction and Loyalty in Taiwanese Leisure Industry. The Journal of American Academy of Business, 9(1), 126132.
Zeithaml, V.A., Bitner, M.J., \& Gremler, D.D. (2006). Service Marketing. New York: McGrawHill.

Zhang, X. \& Prybutok, V.R. (2005). A consumer perspective of e-service quality. IEEE Transactions on Engineering Management, Vol. 52 No. 4, pp. 461-77.

https://www.tabloidpulsa.co.id/news/lifes tyle

https://kominfo.go.id

http://lifestyle.liputan6.com/read/214418 3/5-manfaat-belanja-online

www.apjii.or.id 